\title{
REORGANIZAÇÃO DE SABERES TRADICIONAIS EM LOS SORIAS, DE ALBERTO LAISECA
}

\author{
Graciela Ravetti*
}

\begin{abstract}
Resumo: Neste estudo, propõe-se uma consideração sobre a reformulação de saberes tradicionais em termos não metafísicos na obra do escritor argentino Alberto Laiseca, Los sorias (1998), construída a partir da convergência dos temas das religiões, da magia e da astrologia, lado a lado com outros saberes em face de (des)hierarquização.
\end{abstract}

Palavras chave: Literatura hispano-americana; literatura argentina; romance contemporâneo; ficção científica.

Abstract: In this study, we propose a consideration on the reformulation of traditional knowledge in no metaphysical terms in the work of Argentine writer Alberto Laiseca, Los sorias (1998), constructed from the convergence of the themes of religion, magic and astrology alongside with other knowledge in the face of dehierarchization.

Keywords: Argentine literature; contemporary romance, science fiction, Spanish American literature.

Em estudo sobre Los sorias, de Alberto Laiseca (1941), ainda inédito, desenvolvi a hipótese de o livro ser uma obra-suma, uma ficção pseudo-enciclopédica que podia ser pensada com outras máquinas desmesuradas de narrar, obras-universo, exercício de literatura absoluta - noção desenvolvida por Roberto Calasso -, que

\footnotetext{
"Universidade Federal de Minas Gerais.
} 
diz respeito a um tipo de escrita que é, ao mesmo tempo, livre e autossuficiente, desvinculada de funcionalidade direta, desmarcada de tradições formais estreitas, e que não descarta o que Calasso (2004) pensa em termos da volta dos deuses à literatura, a presença do elemento divino, ao que aqui acrescento o mágico e a delirância maquínica. Em Los sorias (LAISECA, 2004 [1998]) a religião funciona como um problema nada metafísico, de formulação profana: o que fazer com a tradição (a redundância, a recorrência e a conservação de formas de relações de convivência) e o arquivo performático que responde pelo título de religião? Na Tecnocracia - uma das potências em guerra no romance -, coloca-se em funcionamento uma estratégia secular de substituição dos fundamentos metafísicos: constrói-se uma religião num cenário de dissolução de valores religiosos, legitimados por uma certa antiguidade. O corolário dessa ação pode ser enunciado assim: as pessoas convivem com fatos inexplicáveis e não querem prescindir de explicações ainda que, por serem insuficientes os esclarecimentos disponíveis, devem ser, pelo menos, variadas e múltiplas.

No romance de Laiseca, o tema religioso é posto sob o emblema da fraude, da pouca imaginação, da crueldade e do cinismo que alude obliquamente ao grande processo espúrio de fundação das maiores religióes. Remete-se, ainda, ao menos charmoso assunto relacionado com supostas fundações de religiões menos popularizadas e mais recentes que, a espelho das consagradas pela tradição, mostrariam que o modelo se repete, com sacerdotes e generais juntos nas decisões originárias. A partir dessa perspectiva, e como outro termo que completa o leque de respostas aos mistérios da vida, no mundo ficcional de Los sorias, a magia e a astrologia lado a lado com a ciência hiperbolizada, preenchem respostas aos vazios cognitivos e proporcionam bases aos mais extravagantes boatos e crendices disseminadas entre a população. Os problemas específicos religiosos, como os da existência de Deus, por exemplo, não são sequer discutidos nem se reflete sobre eles; a conceitualização do que seria o ser e o anti- 
ser reverte em aplicações a uma ética e a uma moral prática e não em reflexões filosóficas ou teológicas. Assim, o ser faz referência a tudo que tem a ver com uma vida melhor e o anti-ser a tudo aquilo habitualmente relacionado com o mal e com o que não pode ser entendido dentro de um determinado cenário ético, mas que é de ocorrência frequente na sociedade contemporânea.

Vejam-se os seguintes fragmentos de entrevista concedida pelo autor argentino e ressalve-se apenas que a intempestividade do divino na literatura que Laiseca propõe, tão poderosa quanto o da magia, parece confrontar-se com um tipo de dimensionalidade da cultura. Explica Laiseca:

— Jornalista -¿Por qué no el monoteísmo?

- Laiseca -¿Cómo puede ser bueno algo que parte de un principio falso? El monoteísmo parte de una premisa falsa. ¿Vos qué pensarías de Laiseca si viene un día y te dice: "Soy el único ser humano del mundo, todos ustedes son meras proyecciones de mi mente"? En primer lugar que estoy loco, y segundo que soy un hijo de puta, porque te estoy negando a vos como ser humano. Yo no soy el único ser humano del mundo, como tampoco él es el único dios. iSí, hay otras diosas y dioses! iYo los he visto! Llamálos y verás que responden.

- J. - ¿Qué funciones tienen esos dioses?

- L. -Hay distintos, con distintos trabajos teológicos para hacer. Afrodita tiene la función de la delicadeza, del arte, del amor. Marte es la guerra, la voluntad, la purificación. Saturno es la sabiduría, la restricción. Júpiter es expansivo... Entre todas las diosas y los dioses está todo el espectro de lo humano y lo divino.

Uma realização, no romance, e um projeto teórico a ser desenvolvido: distintos trabalhos teológicos para fazer. E que seria, dentro do contexto que Los sorias forja, um trabalho teológico? Vou me deter um pouco mais longamente sobre os capítulos 50 ("La religión de la barbarie") e 51 ("El sumo sacerdote") à procura de uma retórica do divino aí delineada, cuja irrupção resulta em 
um desafio aberto a limites muito naturalizados entre lógicas mais racionalistas ou realistas e outras jogadas no lamaçal da ignorância ou da barbárie contemporâneas.

No livro, fala-se das diversas religiões que convivem nos territórios da Civilização Laiseca - que é como denomina Ricardo Piglia ao mundo ficcional criado em Los sorias por Alberto Laiseca -, e como cada uma delas é mais altero que as outras, bem diferentes do que são as religiões contemporâneas mais conhecidas, sobretudo levando em consideração os limites morais do politicamente correto vigente. Porém, no meio de tanta proliferação religiosa, Monitor (o ditador) sente a necessidade de colocar ordem no caos reinante. "Nos haría falta una religión", afirma, "una que no haga sacrificios humanos, ni efectúe mutilaciones o cosas parecidas" (LAISECA, 2004 [1998], p. 323). O narrador adverte que o que parece uma afirmação cínica na verdade se corresponde com coerência à versatilidade de Monitor, cuja complexa personalidade é composta por abismos e descontinuidades.

Como los cortesanos estaban siempre a su lado con las orejitas enhiestas como misiles y veían que él, pese a ser un hombre religioso, no iba a las pagodas exateístas, taj majales icosaedristas, cavernas orejarias ni cosa alguna, decidieron proponerle la fundación de una religión o Secta Súper Disidente, y que él mismo quedase constituido en cabeza de la misma, como Pontífice Máximo. Tal cual hacían los romanos. (LAISECA, 2004 [1998], p. 323)

No entanto, Monitor prefere começar pela criação de um cargo novo: o Religador ou Sumo Sacerdote, que possui, em correspondência com sua potestade fundamental, o mandato de marechal do campo celestial. Depois de tomar pose, o Religador primeiro supõe que a nova religião vinha a ser um véu para mascarar fins políticos, porém, depois muda sua atitude e propõe a Monitor o que ele acredita ser um ato religioso: um sacrifício a 
Moloch. E, o que é um sacrifício nessa situação? Ele mesmo faz uma espécie de história do sacrifício religioso. Antigamente, explica, esquentava-se a estatua de metal do Deus e se assava "un nenito vivo", mas, os tempos mudaram e com isso as liturgias religiosas. O Religador afirma que só a ideia de queimar um menino vivo o arrepia e sugere a seguinte solução: já que a época é outra, e não resulta possível pensar em sacrifício de vida aos deuses, por que não aproveitar e, retomando a ideia mesma de sacrifício humano, unir o útil ao agradável para se desfazer dos inimigos? (LAISECA, 2004 [1998], p. 323) E não somente se desfazer, também voltar a práticas canibais e antropofágicas: o Sumo Sacerdote postula comer os inimigos convenientemente assados. Monitor aprova a ideia na hora e, mediante um rito que muito se assemelha a qualquer performance do sagrado, a primeira vítima é jogada $a$ la parrilla.

Entre o regime de religiosidade múltipla que havia até o momento em Tecnocracia, com a existência de uma complexa rede de diversas crenças e rituais, essa volta à consagração de uma religião unida ao Estado oferece-se como uma grande paródia que mais que uma ruptura assinala uma carnavalização de toda e qualquer possibilidade de pensamento religioso honesto ou autêntico. Essa parodização de fundação de uma religião, determinada por fatos e atos alheios à vida espiritual tal como concebida no ocidente cartesiano-iluminista, convida a pensar em outros semelhantes que afetaram a história geral, tal como aludido pelo narrador quando remete aos romanos. Volta-se, na religião da Civilização Laiseca, a uma mimese do religioso que lhe é constitutiva. A "passagem" de um tipo de religião a outro está definido no interior de uma história política na qual o reforço do controle se exerce, também, a partir do imaginário religioso, que incute medo, entre outros sentimentos. Na ficção de Laiseca há uma contradição interessante e pulsante de forças. Por um lado, o eterno retorno, a fundação de uma nova religião que parece ou pode iniciar outro ciclo de barbárie moderna; na verdade não tem 
nada de mitológico, no sentido próprio do termo, e sim de artifício político com a finalidade de aproveitar as crenças populares para potenciar o controle social. Por outro, a presença dos deuses: o ser e o anti-ser numa espécie de reconstrução espinoziana, a constante referência às construções wagnerianas e a invocação à mitologia que, não por paródica é menos intensa. A contradição decorre de trazer à baila as duas cenas em simultâneo: a do político abusando e se apropriando do religioso para o controle social e, em contraste, a da naturalidade com que a humanidade transita pelo sagrado, corroborada tal naturalidade pelo tom do narrador que coincide com o do autor, como pode ser observado na intervenção de Laiseca na entrevista citada acima. Para legitimar essa dupla constatação do humano constituído no entrecruzamento entre o material e o sobrenatural, concorrem dois vetores: o demoníaco e maligno ou mesmo e mais especificamente o anti-ser e sua potência destrutiva correndo em paralelo ao ser; as duas são as forças principais que, em sua dinâmica, mantêm em equilíbrio a existência do mundo. As tentativas de utilizar o pensamento religioso com propósitos espúrios ficam neutralizadas pelo desenvolvimento naturalizado e complexo da percepção das forças do divino. Há um largo leque de possibilidades que parece permitir colocar sob uma nova perspectiva tudo que se relaciona com a religião, a mitologia e, como veremos, a magia e a astrologia. Em outros termos: o pensamento religioso e a restauração dos mitos podem servir de alicerce para a performatividade de resistência aos poderes totalitários, a tarefa política por excelência.

A relação entre o temor produzido pelos enigmas $\mathrm{e}$ perigos a que qualquer ser humano está condenado e o consolo que a religião e os poderes sobrenaturais oferecem é uma das dobras evidentes do tema da hierarquização de saberes no romance Los sorias. São duas forças associadas ao não material constatável: uma, que aparece como mal e outra como bem, ou pelo menos construtiva; e ambas podem ser trazidas à ficção romanesca em contextos concretos. Esse trazer à cena artística e à 
conversa contemporânea - à linguagem - as forças que compõem a complexidade do real se percebe em muitas das construções pós disciplinárias que estimulam a epistemologia contemporânea. Na longa reflexão sobre os mitos ocidentais, a era pagã e a nossa podem, numa mesma inspiração, ser recuperadas em algum misterioso momento passível de revelar ou pôr em movimento uma era imaginária, numa cena performática ou teatral, ou em um romance. $\mathrm{O}$ momento performático que traz à tona a morte e o sacrifício como formas possíveis de religar o humano com o não humano, é evidente que só pode, hoje, se servir dos ecos e desdobramentos de um pensamento arruinado, extremo, que põe sob tensão formas do mais arcaico e atávico, e que parece ressoar como paródia, ou como uma grande brincadeira de nonsense. Ou pelo menos, já que essa problemática continua a ter vida ainda no século XXI, pensar em atributos antagônicos a essa imaginação fértil que não deixa morrer certo mundo que ainda sobrevive, parece ser um vigoroso esforço de reconstrução teórica. A história de períodos sinistros da história humana, em qualquer latitude, relampeja em toda sua atrocidade, brilha em presença, como um fato que se atualiza na sua demanda de redenção.

Segundo se conta em Tecnocracia, as velhas crônicas da magia foram soterradas nos Arquivos Blindados tecnocratas. Há, evidentemente, uma implícita contradição na ação de enterrar a memória para melhor lembrar. A um olhar apressado, aliás, isso evidentemente passa também por contrapor ao perigo do esquecimento outro capaz de equilibrá-lo, o risco da memória tomando proporções hiperbólicas e ingovernáveis. Essas histórias, sigilosa e zelosamente vigiadas, contam façanhas de poderosos magos, como as daqueles que viajaram a outro planeta por teletransporte, alguns deles renunciando a voltar, cansados da corrupção, da falta de religiosidade e do esquecimento do planeta natal. Com o objetivo de pesquisar os enigmas do tempo, alguns magos realizaram viagens astrais ao passado, mas nas lutas constantes com os magos do mal, muitos deles foram 
obrigados a ficar presos na história. Houve aqueles que, totalmente desiludidos, transladaram-se a remotas idades para observar os acontecimentos como assistindo um filme sem participar nem se corporizar nesse passado, só na função de observadores fantasmáticos em estado de contemplação, e permaneceram nessa tarefa durante séculos. (LAISECA, 2004 [1998], p. 235) Trechos e partes do enredo como esses, que relacionam o trabalho da memória com a magia, abrem caminho para pensar o compromisso do romance de Laiseca com a ficção científica, na medida em que os arquivos blindados aludem a uma tecnologia científica, as viagens astrais remetem a uma mistura entre a velha magia e a tecnociência do futuro, e os magos, que parecem pertencer às duas dimensões, podem ser percebidos como elos de junção de gêneros literários, verdadeiros promotores do transgênero performático. Tais construções narrativas são habituais e repetidas o suficiente no romance como para imprimir uma nova feição ao terreno disciplinar que ocupam a memória e a história em livre conjunção com as elaborações ligadas ao religioso.

Em Los sorias, o mais inquietante, porém, é que o interesse pelo passado - que poderíamos denominar História - pode tomar proporções indesejáveis e produzir efeitos traumáticos. Por um lado, pode transformar-se em um chamariz encantatório que congela o agente em becos sem saída; por outro, o condicionamento que produz a atração por conhecer a matéria inefável do já acontecido incita elucubrações que fogem aos parâmetros metodológicos das ciências historiográficas e acaba fortalecendo a criação de personagens como os magos historiadores, que se digladiam com o mal no processo de estudar a história, e que chegam até a sucumbir nessas batalhas. E que mal seria esse? E esse discurso sobre a magia e a história, o leitor teria que lê-lo exclusivamente de forma alegórica ou metafórica pela clara impossibilidade de lhe outorgar um referente? Seriam, os magos historiadores, catacreses decisivas da construção desse romance e chaves teóricas destacadas e efetivas para pensar os 
novos realismos produzidos no âmbito da arte da América Latina? Importante notar, contudo, que história e memória colocam a dificuldade máxima para o raciocínio narrativo que sustenta o esquema imagético do romance de Laiseca, e que essa coabitação vai construindo o palimpsesto no qual se sobrepõem as narrativas mágicas e as históricas, aspirando ambas à verdade, ou pelo menos, à possibilidade de entrar no jogo da produção da verdade.

Em certo sentido, é como se, ao propor pensar a história com a magia e a política com a religião, e, ainda, aceitar os agentes - alguns deles - como magos, essa indiferenciação de fundamentos para explicação dos fenômenos da vida possa ser vista como efeito de transladar questões tidas como determinadas a uma zona de evanescência bastante poderosa como para propor novos fundamentos ao que seria uma transdisciplinariedade.

Os deslocamentos mágicos, quando bem sucedidos, são os que possibilitam as profecias, por exemplo, como acontece no caso da personagem Decamerón de Gaula Iseka, que, já no início do romance, é capaz de prever grandes derrotas militares para Tecnocracia. A guerra terrena estaria emparelhada com uma batalha celestial na qual os deuses do bem tentariam destruir o anti-ser e amarrá-lo, com o que acabaria a força desse colosso que tem o poder que tenta arrasar o ser, potência que depois desse fato - se ganhasse a guerra - nunca mais voltaria a fazer sentir seu peso sobre o homem. No entanto, a questão da guerra celestial fica em aberto no romance porque é a Tecnocracia, com seu feroz Monitor já convertido e humanizado, a potência que perde a guerra terrena. A guerra apresenta um espetáculo grandioso, no qual o homem guia a maquinária tecnológica na destruição, e o poder mortífero e alucinante da tecnociência impõe o ritmo fantasmagórico da morte exposta na plenitude do palco, o palco mundano das ações bélicas. Uma performance política e cientificocrata se encena como implementada pela invenção do novo e a recuperação do arquivo no qual todas as máquinas de tortura e de destruição que existiram na história 
acabam colaborando com o terror do presente, potenciado pelo conhecimento adquirido e repassado aos experts. A proliferação de linhas de força que o texto oferece, aumenta a dramaticidade, sobretudo quando se começa a sentir a eficácia da estratégia narrativa de Laiseca de acumular diversas imagens e discursos em construção especular. Com isso, a contraposição de figurações ao longo do romance cobra um sentido definitivo quando se revela uma aporia intransponível, já que nada poderá nunca representar, dimensionar ou abranger de modo certeiro a incomensurável variedade e riqueza da(s) natureza(s) e da cultura(s). Pode-se aceitar que tudo foi jogado no campo da literatura, com o qual se reforçam as dissonâncias aporéticas como alicerces mais claros do que seria em si a literatura, em específico, lugar abstrato onde se travam as batalhas pelo sentido. Nesse campo-contexto, o literário, tudo pode ser dito, gerando uma impressão muito distinta daquela que produziria se fosse enunciado de forma semelhante e com o mesmo teor num ensaio ou em outro tipo de discurso.

Como talvez Bergson imaginou a memória, nos imensos Arquivos de Monitoria não existe seleção: aí cabe absolutamente tudo, todos os dados referentes ao acontecido em milimétrica fidelidade. E, quem pode decidir o que é relevante, se a cada época histórica o que resulta significativo muda ao compasso das conformações culturais? Com certeza, o que realmente importa muito para cada momento histórico representa só uma fração insignificante do que está arquivado, se comparada com o total dos dados. Afinal, parece que aos magos historiadores correspondem os magos escritores, já que essa aparente infinitude de dados só poderia vir a servir para um romancista, por exemplo, como material para uma narrativa, resíduos que são só aptos para o fazer estético. Todos estes registros são mantidos, na Civilização Laiseca, pelo trabalho de Grandes Máquinas com defesas carimbadas e pranchas de chumbo para evitar a sua destruição. Novamente é evidente o paradoxo: para evitar a destruição é necessário um tal cuidado na preservação que o guardado fica totalmente impedido de ser consultado e compartilhado. 
Tudo está guardado com a mesma precaução, sem hierarquias nem processos de significação. Não há aí a figura do arconte, nem o olhar de quem sabe e tem a autoridade para gerenciar o arquivo. Decamerón de Gaula, o grande mago de Tecnocracia, acalenta a esperança de que algum dia um escritor venha a ser capaz de escrever o romance da Tecnocracia: uma obra integral, com todos seus sonhos e alternativas, seus projetos cumpridos e os fracassos, uma gesta, uma epopeia de fluxos históricos. Em um trabalho assim, cuja proposta seja a plenitude, o ascetismo teria que ficar de fora; as imagens seriam inúmeras, uma espécie de barroco borgeano. Em mais uma figuração especular do próprio romance, o procedimento da simetria acumulativa que Laiseca pratica, Decamerón exprime suas lamentações imaginando o véu de esquecimento que se abaterá sobre tudo o que existe para ele. Seu sofrimento deriva de que depois da derrota anunciada de Tecnocracia e, tal como acontece em toda derrota, só os vencedores cantarão os fatos da história, o esquecimento histórico será total e absoluto e tomará conta de todo o acontecido, que será dissolvido no tempo e no espaço. A única esperança que lhe resta é a da arte do romance, do cinema ou das artes plásticas, que poderiam, hipoteticamente, manter um elo de continuidade na redundância conservadora para que, em uma completa indistinção entre literatura e história, e aproveitando todas as ferramentas de que a arte é capaz de convocar pela tradição da estética, e ainda que tudo ficasse numa nebulosa - tipo romance de cavalaria teria, pelo menos, assegurada alguma forma de sobrevivência. $\mathrm{O}$ mundo da Tecnocracia, seus habitantes, os governantes, os magos, todo aquele império de maravilhas tecnológicas seria abatido pelo vento da história e pelo progresso, e tudo seria subsumido pelo violento furacão da guerra e os efeitos das diretrizes políticas dos novos donos do poder. Talvez o romance que o leitor tem nas mãos seja a reconstrução sonhada por Decamerón, funcionado como uma formulação estética quase ilegível, caótica e destinada a ser mal lida ou simplesmente não lida. 
Como estou argumentando, no romance de Laiseca, a guerra entre superpotências pela primazia do poder no mundo se disputa em pelo menos dois níveis: o terreno e o sobrenatural. Duas tensões são perfeitamente visíveis na narrativa. A primeira, ecoando a ficção científica, entre as alucinações futuristas com base na ciência e as fabulações, a partir da tecnologia. A segunda, entre ciência e magia. A tecnociência fantasmagórica e a magia estão postas, em Los sorias, como saberes e poderes a partir dos quais se contam histórias com a imperturbabilidade de um escritor realista descrevendo o que conhece perfeitamente bem e organizando e decifrando o mundo que tem ante seus olhos. A magia, responsável por prodígios e portentos, é também tratada como uma técnica antiga e eficaz, utilizada desde tempos imemoriais para negociar uma relação favorável com os deuses e para propor sentidos mediante imagens, símbolos, gestos, cantos, rituais de todo tipo, que permitiram e permitem que a abstração conceitual seja materializada pela proximidade imagética e simbólica. Movimento semiótico esse que resulta inesgotável porque a atribuição de sentidos se realiza de forma catacrésica, ou seja, sem compromisso com um referente extra textual ou extra discursivo: trata-se de uma perene transmutação de signos e significados criando um corpo de doutrina alternativa. O tempo que transcorre imperturbável, as tragédias climáticas, a morte sempre iminente, as doenças, a fome, os sofrimentos, tudo pode ser equacionado por um pensamento mágico, ressignificado, ordenado para apresentar uma resposta ao caos e ao nada. A relação particular aproximante entre quem conhece e o que é conhecido é uma das explicações mais racionais da insistente persistência da magia na vida humana, talvez, pela condição performática que a prática da magia possui ao se basear em elementos concretos, visuais, auditivos, corporais e por exigir o comprometimento de quem necessita dela e de quem atua como oficiante.

A magia não permite a mediação nem a intermediação, se realiza corpo a corpo, não se pode pensar em magia sem aludir 
a comportamentos definidos por uma tradição, que são sempre renovados pelos executores que demonstram habilidades e que com isso ganham legitimidade nas comunidades nas quais se atualizam as práticas. No entanto, a magia é também uma forma de textualizar a história, de estabelecer elos de continuidade alternativos que possibilitam a sobrevivência de uma comunidade ou de uma sociedade como um todo. E essa textualidade está pontuada por liames e entraves de muita complexidade, com significações culturais locais, entranhadas na vida dos grupos. No centro, no coração dessas comunidades se estabelecem as hierarquias entre os que detêm o poder, porque estão mais próximos dos deuses e dos pontos que a imaginação humana sempre teve como inalcançáveis origens, porque demonstram possuir poderes extraordinários e os que servem de enlace entre a natureza e a humanidade, encarregados do trabalho de sustento. Essa escrita social organiza a convivência e a vida das comunidades com base nas capacidades de trabalho e na insistência para a aprendizagem que transforma alguns homens em mestres e outros em discípulos. Tudo isso destaca os que serão os grandes magos, os xamãs do conjunto, separados daqueles que ficam incluídos na condição de necessitados, vítimas ou simples protegidos.

Em Los sorias, como nos livros de cavalarias e nas histórias de ficção científica, a guerra se dirime por combates nos quais intervêm componentes mágicos e exóticos, animais fantásticos, criaturas sobrenaturais, personagens com poderes extraordinários, rituais esotéricos em atuação material e concreta, formas temporais que implodem a concepção ordinária de tempo e de espaço. Há outros jogos possíveis, além do racional: Magia e técnica, magia e guerra. Magia e religião. Magia e política. Vejamos um trecho bastante explicativo do funcionamento do complexo dispositivo social e cultural da Civilização Laiseca, alimentado por saberes alternativos organizados em outras hierarquias das consagradas em Ocidente ou mesmo des-hierarquizados. 
Todos los gobiernos poderosos de aquel entonces tenían sus equipos de magos que hacían trabajos esotéricos. Tales tareas herméticas consistían, en general, en leer a distancia documentos secretos, apoyar o proteger mágicamente operativos militares o de cualquier otra naturaleza, asesinar enemigos poderosos y contrarrestar la acción de magos adversarios. Los ocultistas tecnócratas, que eran poderosísimos aunque relativamente pocos comparando con los de los demás países, cuando querían leer los registros afásicos a fin de averiguar qué misterioso agente interfería desde La Selva veían en el astral una suerte de pared blanca impenetrable. Era como si toda la selva estuviese blindada y no podían observar cosa alguna. Entonces, un buen día, se decidieron a trabajar todos juntos para sacarse la duda. Uniendo sus fuerzas crearon una especie de cono de penetración a fin de perforar el blindaje en un único punto. Lanzaron una energía capaz de hacer desaparecer a la mitad de Soria. Y nada. Se esforzaron hasta quedar exhaustos. No había caso. Siempre la implacable pared blanca que los rayos afásicos no podían penetrar. Finalmente desistieron pues estaban muy cansados y los magos de Soria podían aprovechar para atacar a la Tecnocracia o, cuando menos, asesinar al Jefe de Estado. (LAISECA, 2004 [1998], p. 113)

No mundo de Los sorias existe a guerra esotérica sobre a qual o povo nada sabe, salvo pelos efeitos que recaem sobre ele. Os sentimentos e as paixões dos grandes magos em nada diferem do comum, por isso eles se digladiam em nome de suas nações, em uma espécie de representação que se auto-legitima. A magia, neste romance, padece das mesmas restrições que quaisquer outras habilidades e potências humanas: os magos têm limites, que são os outros magos com poderes mais ou menos equivalentes. Por isso, para eles são também necessárias as estratégias, a solidariedade, as teorizações prévias e posteriores aos atos, as responsabilidades conscientes. É fundamental para a sobrevivência o respeito pelos poderes dos outros. 
Para estabelecer uma certa estabilidade referencial do romance de Laiseca, ainda que de uma forma bastante tangencial, é útil o cotejo do mundo da magia criado na ficção com algumas fontes que proporcionam dados sobre a magia, como prática reconhecida e como narrativa consolidada ao longo da história cultural. Tais fontes dependem, em grande medida, da perspectiva conceitual dos pesquisadores e do marco objetivo metodológico que se impõe na análise dos dados. Podem se encontrar proposições que dão conta da existência da magia a partir das inscrições da pintura rupestre na cavernas do homem pré-histórico até a afirmação de que originalmente os magos teriam sido uma casta sacerdotal persa fundada por Zoroastro, como os druidas entre os celtas, ligados à religião e cujo saber fora transmitido pelos gregos e chegara até a contemporaneidade. Mais tarde, essa original magia teria ido se misturando com a feitiçaria, os conhecimentos astronômicos, as artes adivinhatórias, a astrologia, a alquimia. Os gregos deixaram relatos que aludem a práticas mágicas em sintonia com o que era dos deuses, como pode ser lido na Ilíada, na Odisseia, em peças teatrais e em textos de medicina. Ao se observar com algum detalhe o que se pode dizer hoje sobre a magia, destaca-se um componente que se aduna com o que trato a respeito do romance total: pode tudo, é difícil colocar um limite a um mago, exceto pela ação de outro mago, seu oponente; os rituais são secretos e incompreensíveis para um ser comum e os métodos de atribuição de significado são herméticos até o ponto de que o conceito de aleatório é perfeitamente cabível para defini-los. Por essas e outras razões a magia foi perseguida e isolada, criminalizada, especialmente desde os tempos nos quais o racionalismo iluminista entronizou a razão como fiel da balança e impôs quais eram as zonas racionais e quais não, e, por consequência, o que deveria ficar na margem do mainstream da lógica do sistema cultural humanista ocidental e, se possível, cair no mais profundo esquecimento. A magia foi uma dessas áreas condenadas, mas, nem por isso deixou de ter desenvolvimentos artísticos, conceituais e de práticas culturais. 
De cientistas até divulgadores de técnicas de autoajuda, há um consenso em chamar natural a magia que apela a forças ou poderes que se pensa estar objetivamente presentes na natureza. Platão, no Simpósio, definiu com naturalidade os demônios como seres intermediários morando em um além da terra quase céu, e lhes atribuiu uma função mediadora entre o humano e o que o ultrapassa. Isto é interessante porque justamente esse diálogo é considerado por parte da crítica como uma obra de Platão que poderia se considerar quase um novel, talvez o primeiro novel da história. E essa forma parece servir a Platão para colocar na boca de Sócrates a condição insolúvel o paradoxo de pensar o lugar do humano, na encruzilhada entre o particular e a abstração, a ambígua relação entre a individualidade e a universalidade. No Banquete, Platão afirma que Eros é um mago (GRISWOLD, 2008, p. 205-216) ; Apuleio, no século II d.C. escreveu Apologia, dividida em duas partes, como defesa da acusação de ter utilizado a magia para se casar e se apoderar dos bens de sua esposa. $\mathrm{Na}$ argumentação de Apuleio, a magia não é outra coisa que o nome que os ignorantes dão à filosofia. Ele distingue, no entanto, dois tipos: um, do vulgo, que seria criminal por seus objetivos e efeitos; o outro, que se baseia no conhecimento da ordem natural das coisas, seria a própria de sacerdotes e filósofos, interessados no conhecimento. Mais tarde, já na Idade Média, a relação entre a magia e o hermetismo estabeleceu outros entraves de mistério e propiciou o surgimento de uma rede profusa de estudiosos e praticantes, de curiosos e diletantes, de pensadores e de oficiantes que se complicou extremamente com o perigo que representou a Inquisição. No Renascimento, Ficino formaliza a magia natural e a coloca no centro de sua reflexão filosófica: o mago Eros sublime, motor da criatividade que aspira à imortalidade da alma, núcleo da história religiosa do homem, esse Eros que, na procura da beleza, transforma toda estética em uma ética e amor divinos. Em 1484, ano da publicação de De amore, de Ficino, é também a data da publicação de Malleus maleficarum, conhecido como Martelo das bruxas, escrito pelos inquisidores dominicos Kraemer 
e Sprenger, autorizados pelo papa Inocêncio VIII' ${ }^{1}$, De occulta philosophia libri tres de Cornelius Agrippa e a Magia naturalis de Giambattista della Porta. Santo Agostinho distingue três tipos de magia: a teúrgia, a magia propriamente dita e a goecia. A goecia é a pior das magias, a teúrgia, a mais sublime, porém, é comum às três tanto a violência que exercem sobre os poderes superiores, quanto a procura de efeitos fora do normal. Cada demônio e Deus têm nomes, e saber o nome do demônio acrescenta poderes ilimitados ao mago, por isso, conhecer o nome do outro é o grande segredo profissional, o máximo grau da sabedoria mágica.

Existe a reivindicação de reconhecimento do estatuto de ciência para a magia com base na alegação de ter desenvolvido uma base experimental de regras para uma prática concreta e explicações para os efeitos dessas práticas. A técnica e os procedimentos mágicos são especialmente insólitos para quem desconhece a arte, mas uma das condições de existência da magia é precisamente a repetição em detalhes, a recorrência, a tradição, a memória performática, e, em teoria, a possibilidade de duplicar as experiências como em uma ciência qualquer com reconhecimento institucional. Não é que não possam advir renovações, novas informações que venham a modificar os saberes mais antigos. Porém, a reapresentação das funções dos magos em suas formas tradicionais representa uma forma de conhecimento metafórico e com propriedades metamórficas, não muito distante de como operam os saberes do literário (artístico, por extensão) e da cognição, notadamente os da memória afetiva. A tradição

${ }^{1} \mathrm{O}$ livro foi aprovado por bula papal de Inocêncio VIII e teve uma ampla difusão por suas instruções sobre como identificar as bruxas. O livro descreve a influência do demônio nas mulheres e a forma de identificar a bruxaria, bem como explica o modo em que as feiticeiras devem ser julgadas e punidas. Entre os anos de 1487 e 1520, teve 13 edições, e entre 1574 e 1669, dezesseis. A influência desse livro em grandes obras da época, como Paradise lost, de Milton, está sendo descoberta aos poucos. Veja-se, por exemplo, o livro de Peter Broedel: The malleus maleficarum and the construction of witchcraft: theology and popular belief studies in early modern european history (2003). 
em teorias sobre magia pode ser rastreada desde Edward B. Tylor e James Frazer, Marcel Mauss e Emile Durkheim, a Lucien LévyBruhl e Claude Lévi-Strauss ${ }^{2}$ dentre outros, muito contestados na atualidade por outros desenvolvimentos sobre o tema. Só as abordagens mais recentes integram a magia dentro do quadro maior da história das ideias, ainda que como elemento de um campo esotérico do discurso, um tipo de idiossincrasia ou excentricidade; contudo, esse gesto já supõe um ganho e lhe dá ao campo uma certa visibilidade, pelo menos não pode se ocultar ou excluir como se não existisse. A magia, junto com a astrologia, cujo longínquo passado até a Bíblia testemunha e cujos primeiros cultores talvez teriam sido os sacerdotes caldeus, encontra-se com certa facilidade em textos medievais que contêm horóscopos, previsões, tipos de personalidade, destinos individuais, amor, poder, negócios, teoria cosmológica, alquimia, agricultura e medicina. Na Idade Média, a astrologia e a astronomia chegam da Grécia ao Ocidente de forma fragmentada, através de textos tecnicamente pouco refinados e sempre condenados pela Igreja católica. No Oriente, a astrologia grega foi transmitida ao mundo árabe, chegando, através dele, à Península Ibérica, por volta do final do século X. No século XII, a astrologia adquire grande ímpeto com a redescoberta e tradução do grego para o latim de textos preservados pelos árabes e de textos árabes relacionados a ela, e também à astronomia e à filosofia. Em muitas cortes da Europa Medieval, os governantes recebiam aconselhamento astrológico de médicos e membros da corte. Apesar de regularmente condenada pelos teólogos, o uso frequente da astrologia pode ser evidenciado por vários manuscritos medievais que chegaram até os dias de hoje. A arte da astrologia estava dividida em duas partes principais: a mundana (também chamada de geral ou natural) e a judicial. A primeira concernia às influências celestes

\footnotetext{
${ }^{2}$ Ver o estudo de Mayer (2009); Tylor (958); Frazer (1959); Mauss (1972); Durkheim (1976); Lévy-Bruhl (1928). Para uma introdução concisa sobre o tema, ver também Hanegraaff (2005, p. 716-719) e Cunningham (1999).
} 
sobre os fenômenos naturais, tais como o tempo e a previsão de acontecimentos em geral. A segunda preocupava-se com a vida do indivíduo e o momento certo para realizar alguma ação, vista com suspeita pela Igreja católica e pelo judaísmo tradicional, já que tinha potencial para pôr em dúvida o conceito do livre arbítrio da divina providência de Deus. Uma resposta comum a essa crítica, por parte dos astrólogos, era a de que a astrologia preparava os seres humanos para eventuais desastres, diminuindo seu impacto, sem que isso implicasse a posse de algum poder maligno ou qualquer desafio aos poderes divinos, tal como definidos pela Igreja na época. Ademais, apenas os corpos, paixões e multidões eram regidas pelas estrelas; a razão, as almas e o livre arbítrio dos indivíduos estavam fora de sua esfera de influência. É difícil saber o quão abrangente era a disseminação das ideias astrológicas e das práticas mágicas. O hábito difundido da leitura em voz alta e, portanto, coletiva, pode ter aumentado a transmissão das crenças e das práticas astrológicas, mas o mais provável é que a medicina astrológica tenha sido a forma mais comum de exposição dessa área do conhecimento (DUCHOWNY, 2007, p. 17-18). Entre a leitura por diversão, ócio e divertimento e o desespero humano ante o sofrimento físico e a morte, está desenhado o arco de estímulo tanto da magia quanto da astrologia. Esses arquivos do conhecimento antigo que se conserva só em farrapos, em restos de suportes materiais, em narrativas orais e em certos documentos considerados históricos e que por momentos alcançam estados de luminosidade quando focalizados pela literatura, é o que fascina e relampeja no romance que estou discutindo. E em grande parte dos romances extensos de todas as épocas.

Quando se aborda a leitura de um universo elaborado como o de Laiseca, o leitor se choca com uma sociedade que conserva vivos aqueles alicerces descartados como lixo histórico. Ante um mundo humano diferente e assustador, é como se os contemporâneos não pudessem compreender exatamente o aspecto da civilização à qual se ligam e somente fosse por mediação 
dos artistas que acaba ressurgindo o passado, dando vida a ruínas do pensamento. Tal como sonhara a personagem Decamerón de Gaula. O gigantesco e sempre renascente arquivo literário funciona como um transgênero performático quando aceita e dá forma a quaisquer construções humanas, de todos os tipos. Em Los sorias, o elemento mágico é constante, está imbricado no discurso como normal e corrente. Decamerón de Gaula Iseka, como o intrigante chefe da equipe de magos, astrólogos e médicos bruxos que rodeiam ao Monstruoso Señor de la Tecnocracia é capaz de dispor de um completo domínio do conhecimento teórico e aplicado das ciências esotéricas.

Decamerón de Gaula le dijo en cierta ocasión a Coco Iseka (uno de sus discípulos):

Escuchá, Coco. Te voy a leer un pedacito de El espía que me amó, de Ian Fleming: "La verdadera vida del hampa raras veces es vista por el hombre de la calle. Pero existe. Uno juega a carta errada, y está perdido. Perdido en un mundo que no conocía, y del cual no sabe cómo defenderse."¿Qué tal si a ese fragmento yo le agregase unas pocas palabras? ¿Eh, Coco? Vas a ver cuánto más profundo suena: "La verdadera vida del hampa mágico, del hampa sobrenatural, raras veces es vista por el hombre de la calle. Pero existe. Uno juega a carta errada, y está perdido. Perdido en un mundo que no conocía, y del cual no sabe cómo defenderse. Cuánto más siniestro resulta así, ¿no? ¿Qué sabe la gente común del poder de las Sociedades Esotéricas que patrullan las ciudades? ¿Qué saben los ciudadanos normales de la realidad de cientos y miles de tipos que caminan por las calles más transitadas, haciendo mudras y lanzando sobre sus víctimas indefensas energías que pueden enfermar, castrar, matar?

Coquito respondió:

-Tendríamos que escribir algo así como una novela, Maestro. Para prevenir a la gente.

- Tendríamos. Pero nadie creería una palabra. Lo tomarían como un delirio literario. (LAISECA, 2004 [1998], p. 229) 
Em La civilización Laiseca, prólogo de Ricardo Piglia a Los sorias, o crítico opina sobre este tema, central no romance:

Quiero decir que el repertorio de lo que llamamos literatura argentina no forma parte del horizonte de Laiseca: tiene otros escritores y otras tradiciones en la cabeza. Por ejemplo admira a Mika Waltari (Sinuhé, el egipcio), y a veces (cuando está desanimado) piensa en Joyce y puntualiza que Los sorias es más grande que el Ulysses. Tiene razón, lo ha medido y le lleva (Laiseca a Joyce) una ventaja de 30000 palabras. (LAISECA, 2004 [1998], p. 7)

No trecho citado, o narrador de Los sorias fala sobre Ian Fleming, o criador do agente 007, James Bond, e a citação que a personagem faz de Fleming é ainda comentada e modificada. Vê-se que a referência a esse tipo de literatura "popular" ou "de massa" não que as duas expressões possam ser consideradas equivalentes em todas suas acepções, porém, sim o são neste particular - não é um ornamento, na medida mesma em que a energia colocada no trabalho de desdobrar o trecho e reescrevê-lo aumenta a qualidade do investimento intencional de concentração numa dada área textual e revela um método de trabalho na elaboração do romance. Essa heurística implica uma seleção temática, uma filiação a leituras e a linhas discursivas - escrever um romance para informar, propõe o discípulo -, um constructo retórico narratológico - o romance de aventuras de espionagem -, cujo efeito, lamenta a personagem, não seria o esperado: as pessoas não acreditariam na verdade do romance. Fontes populares e literárias sobre saberes menos prestigiados - a magia e a astrologia -, leituras que transgridem a hierarquização canônica do literário conformam a linguagem específica deste escritor argentino para cujo método tudo é instrutivo e fungível, nada é descartável no intuito de dar vida aos tropos que criam a realidade "da ficção para a ficção". Nesse último sentido, vê-se o recurso ao tropo básico da catacrese - que constrói uma referência não referencial, não 
constatável pelos sentidos -, que, entre outras consequências, atualiza elos com tradições antigas e medievais, e passa pelos séculos com a familiaridade de um viajante do tempo: $\mathrm{O}$ Amadis de Gaula, mas também O anel do Nibelungo, só para mencionar alguns dos mais evidentes e destacados no romance, entram na composição enunciativa da ficção em uma dimensão não previsível pela hierarquização cultural, ao passo que abre para o leitor atento uma nova perspectiva de leitura, já que o próprio romance se coloca como um desdobramento de outros textos - só para mencionar alguns que comentei em outros trabalhos, Adán Buenosayres, de Leopoldo Marechal e o anônimo Amadis, 1984 de George Orwell - e, assim, acaba demandando novas leituras da tradição. 


\section{Referências}

AGOSTINHO. The city of God. Livro X, Capítulo 9. Disponível em: $<$ http://www.newadvent.org/fathers/120110.htm >.

AMADÍS de Gaula. Ed. de Juan Manuel Cacho Blecua. Madrid: Cátedra, 1987-1988.

BROEDEL, P. The malleus maleficarum and the construction of witchcraft: theology and popular belief studies in early modern european history. Manchester / New York: Manchester University Press, 2003.

CALASSO, R. A literatura e os deuses. São Paulo: Companhia das Letras, 2004 .

CALASSO, R. As núpcias de Cadmo e Harmonia. Trad.Nilson Moulin Louzada. São Paulo: Companhia das Letras, 1990.

CALASSO, R. La poética de los dioses: entrevista a Guadalupe Alonso y Mauricio Molina. Disponível em <http://www.revistadelauniversidad. unam.mx/1505/pdfs/73-80.pdf >; acesso em 10.02.2014.

CUNNINGHAM, G. Religion and magic: approaches and theories. Edinburgh: Edinburgh University Press, 1999.

DUCHOWNY, A. T. De magia (ms. laud or. 282, Bodleian Library): edição e estudo. Tese (Doutorado em Estudos Linguísticos) - Faculdade de Letras, Universidade Federal de Minas Gerais, Belo Horizonte, 2007. DURKHEIM, É. The elementary forms of religious life. London: Allen and Unwin, 1976.

FICINO, M. Sobre el furor divino y otros textos. Barcelona: Anthropos, 1993.

FOLEY, R. The theory of epistemic rationality. Harvard: Harvard UP, 1987.

FRAZER, J. The golden bough: a study in magic and religion. London: Macmillan, 1959.

GRISWOLD, C. L. Reading and writing Plato: philosophy and literature. Baltimore: The John Hopkins University Press, 2008. V. 32.

HANEGRAAFF, W. J. New age religion and western culture: esotericism in the mirror of secular thought. New YorK: SUNY, 1998. 
HANEGRAAFF, W. J. Magic I: introduction. in: dictionary of gnosis and western esotericism. Leiden: Brill, 2005. p. 716-719.

LAISECA, A. Entrevista, 1993. Disponível em < http://www. paginadeeducacion.com.ar/elearning/topic.asp?TOPIC_ID $=1272>$; acesso em 10.02.2010.

LAISECA, A. El gusano máximo de la vida misma. Barcelona: Tusquets, 1999.

LAISECA, A. El jardín de las máquinas parlantes. Buenos Aires: Planeta, 1993.

LAISECA, A. Los sorias. Prólogo de Ricardo Piglia. Buenos Aires: Gárgola, 2004 [1. ed., 1998].

LÉVY-BRUHL, L. Les fonctions mentales dans les sociétés inférieures. Paris: Alcan, 1928.

MALINOWSKI, B. Magic, science and religion and other essays. New York: Doubleday Anchor Books, 1948.

MARECHAL, L. Adán Buenosayres. Buenos Aires: Sudamericana, 1984.

MAUSS, M. A general theory of magic. Londres: Routledge, 1972. [1. ed., 1902]

MAYER, G.Magicians of the twenty-first century: an attempt at dimensioning the magician's personality. Magic, Ritual, and Witchcraft, Philadelphia, v. 4, n. 2, 2009.

ORWELL, G. 1984. 29. ed. São Paulo: Companhia Editora Nacional, 2005. RANCIÈRE, J. A partilha do sensível. São Paulo: Editora 34, 2005.

RANCIÈRE, J. A política da literatura. São Paulo: Editora 34, 2005.

TYLOR, E. B. Primitive culture: researches into the development of mythology, philosophy, religion, language, art and custom. New York: Harper, 1958

Recebido para publicação em 30 de dezembro de 2013 Aprovado em 05 de abril de 2014 